\title{
Effect of Gamma Radiation on Protein Profile, Protein Fraction and Solubility's of Three Oil Seeds: Soybean, Peanut and Sesame
}

\author{
Abd El-Moneim M.R. AFIFY, Mohamed M. RASHED, Ebtesam \\ A. MAHMOUD, Hossam S. EL-BELTAGI* \\ Cairo University, Faculty of Agriculture, Department of Biochemistry, P. Box 12613, Gamma \\ st, Giza, Cairo,Egypt; lbltg@yahoo.com ( ${ }^{*}$ corresponding author)
}

\begin{abstract}
The proteins properties of three oil seeds (soybean, peanut and sesame) were investigated following $\gamma$-irradiation $(0.0,0.5,1.0,2.0$, 3.0, 5.0 and 7.5 KGy). The effect of $\gamma$-radiation on total protein solubility, albumin, globulin and SDS-ME fractions were studied using SDS-polyacrylamide gel electrophoresis. The results showed that solubility of total protein were decreased and reached to the maximum decrease using irradiation dose of 7.5 KGy compared to control. The interesting phenomena are that albumin and globulin fractions decreased in its solubility while the SDS-ME fraction increased. These phenomena may be due to the effect of gamma radiation on the protein, which may dissociate this fraction to small subunits, and rearrangement to form a complex protein even high or small molecular weight proteins solubilized only in SDS-ME fraction. The changes in protein profile were depended even on radiation dose and on the nature of oil seeds; soybean, peanut and sesame.
\end{abstract}

Keywords: electrophoresis, gamma irradiation, peanut, protein solubility, sesame, soybean

Abbreviations: SDS-sodium dodecyl sulfate; ME-2-mercapto ethanol, KGy-Kilo gray

\section{Introduction}

Soybean is a protein rich oilseed crop, which is presently the leading edible oil source throughout the world. Though soy protein ranks high compared to other vegetable proteins, it is still of poor nutritional quality compared to animal proteins. Soy protein isolates consist of $90 \%$ protein; their major components are glycinin (11S), and $\beta$-conglycinin (7S), which represent $34 \%$ and $27 \%$, respectively (Iwabuchi and Yamaucho, 1987a, b). The rest of the proteins consist of whey proteins, such as $\gamma$ conglycinin (trimer of $170 \mathrm{KDa}$ ) (Hirano et al., 1987), the basic 7S globulin, lipoxygenase, agglutinins, and $\beta$-amylase, which belong to the 7S fraction (Iwabuchi and Yamaucho, 1987b). It is known that the physiochemical properties of proteins are modified by irradiation as reported by Hafez et al. (1985), Afify and Shousha (1988) demonstrated that $\gamma$-irradiation caused molecular changes resulting in condensation or polymerization, degradation, hydrogen-bonding distribution and cleavages of intermolecular disulphide bonds (Casarett, 1968). Therefore, it is assumed that such molecular rearrangements bring about changes in secondary structure and distribution of the native conformation of soybean proteins, especially at higher dose levels. Afify and Shousha (1988) reported that SDSPAGE proved that changes in protein subunit patterns could be identified in the 'Clark' cultivar depending to dose of $\gamma$-exposures. Three high molecular weight protein bands were detected in irradiated soybean cultivars by using Poro-PAGE 5-25\% polyacrylamide.
Chiou et al. (1990) purified arachin and conarachin from peanut seeds by phosphate buffer and characterized on SDS-PAGE gel. Data revealed that arachin was composed of five major subunits with molecular weights (MW) of 42, 37, 35, 22 and $20 \mathrm{~K} \mathrm{Da}$ and four minor subunits with MW of $66,31,29$, and $25 \mathrm{~K} \mathrm{Da}$. Conarachin represent the major one subunit with a MW of $64 \mathrm{~K} \mathrm{Da}$ and three minor subunits with a MW of 60,32 , and $21 \mathrm{~K}$ $\mathrm{Da}$ (El-Beltagi, 2011). The irradiation caused native protein aggregation might simply result from rearrangement of the composed protein subunits (Sonntage, 1987) and crosslinking of peptides or proteins to form dimers or tetramers through the action of free radicals and produced from $\gamma$-radiation. Cross-linking of proteins electrophoresis pattern was also observed in the microwave irradiation of canola meal performed by Sadeghi and Shawrang (2006). However, Lee et al. (2005) reported that gamma irradiation affects proteins by causing conformational changes, oxidation of amino acids, and formation of protein free radicals. Also, chemical changes in the proteins caused by gamma irradiation include fragmentation, cross-linking, aggregation and oxidation by oxygen radicals that are generated in the radiolysis of water. Gamma irradiation has a slight effect on the amino acid profile at recommended doses to foods (WHO, 1999). The chemical nature of damage in irradiated proteins has been explained by molecular rearrangements resulting in condensation or polymerization (Carroll et al., 1952), degradation (Schweigert, 1959), hydrogen bond disruption and cleavages of intermolecular disulfide bonds (Casarett, 1968; Dogbevi, et al., 1999a). 
Sulphydryl (-SH) and disulphide (-S -S) groups in proteins are apparently more sensitive to irradiation (Lee, 1962), at very high doses of radiation, reduction in cystine content of wheat has been reported (Doguchi, 1969). The observed increase of some free amino acids in irradiated red gram, wheat, casein and shrimp could be due to a breakdown of proteins (Néné et al., 1975).

Sesame (Sesamum indicum L.) is a very ancient oilseed crop and one of the earliest domesticated oil crops in the world. It acquired importance as a source of cheap vegetable oil and proteins, good source of natural antioxidants (sesamin and sesamolin) which are unique for sesame and present in the oil (Ashri, 2007). Ionizing radiation has been routinely used to generate genetic variability for breeding and genetic studies. Mutagens used may cause genetic changes in an organism, break linkages and produce many new promising traits for the improvement of crop plants (IAEA, 1977). Induced mutation is highly instrumental in plant biology to induce genetic variability in a great number of crops (Siddiqui and Khan, 1999). Therefore different protein composition of the irradiated sesame will be studied extensively. Gamma rays cause different degrees of cell damage. Biological damage is mostly in direct, and mediated by reactive oxygen species (ROS), such as hydroxyl radical $(\mathrm{HO})$, superoxide radical $\left(\mathrm{O}_{2}{ }^{-}\right)$, hydrogen peroxide $\mathrm{H}_{2} \mathrm{O}_{2}$, single oxygen, etc., generated by the radiolysis of water (El-Beltagi et al., 2011). These reactive species are known highly reactive to membrane lipids, protein and DNA. They are believed to be the major contributing factors to stress injuries and to cause rapid cellular damage (Afify and El-Beltagi, 2011; Afify et al., 2011; Aly and El-Beltagi, 2010; El-Beltagi et al., 2008; 2010; El-Beltagi and Mohamed, 2010; Ibrahim et al., 2011; Kobeasy et al., 2011; Mohamed et al., 2009; O'Kane et al., 1996; Salama et al., 2009; Shehab et al., 2010), particularly when plants are exposed to stress conditions such as chilling stress, salt stress, Fe deficiency, cadmium stress, Lead toxicity, ionizing radiation, insecticide, organisms and micro-organisms to caused degradation of important macromolecules, including DNA and cell membranes.

The main purpose of this investigation was to study changes in protein profiles in addition to total protein solubility, albumin fraction, globulin fraction and SDS-ME fraction of three oil seeds (soybean, peanut and sesame) as a results of gamma irradiation with range of 0.5 to 7.5 KGy.

\section{Materials and methods}

Soybean seeds (Glycin Max L. var. 'Clark'), peanut seeds (Arachis Hypogaea L. var. 'Giza 5') and sesame seeds (Sesame indicum L. var. 'Giza 32') were obtained from Food Legumes Research Department, Field Crops Research Institute, Agricultural Research Center, Giza, Egypt, during season 2008.

\section{Gamma iradiation treatments}

Irradiation treatments were performed by using Cobalt 60 source from unit Gamma Chamber 4000; at the National Center for Research and Radiation Technology, Naser City, Cairo. Samples were irradiated at 0.5, 1, 2, 3, 5 and7.5 kGy (75\%) in the gamma cell (gamma facility PXg-30 irradiator model, Russia) at room temperature and in the presence of air. The dose rate was $4.166 \mathrm{rad} / \mathrm{second}$ $(75 \%)$ as measured by ethylene mono-chloro-benzene dosimeter (ECB).

\section{Extraction of proteins}

\section{Extraction of total protein fraction (Albumin + Globulin)}

Defatted peanut and sesame meals were extracted with sodium phosphate buffer $(0.2 \mathrm{M}, \mathrm{pH}$ 7.9) containing $0.02 \% \mathrm{NaN}_{3}$ at $4^{\circ} \mathrm{C}$ as described by Chiou and Tasi (1990). Defatted soybean meal was extracted with 0.03 $\mathrm{M}$ Tris- $\mathrm{HCl} \mathrm{pH} 8.0$ buffer at room temperature to yield whole buffer extract as described by Iwabuchi and Yamauchi (1987b), then centrifuged at $3000 \mathrm{~g}$ for $30 \mathrm{~min}$ at (Ali and Olivo, 2002).

\section{Extraction of albumin fraction}

Defatted samples were extracted with distilled water containing $0.02 \% \mathrm{NaN}_{3}$ and then centrifuged at $1500 \mathrm{~g}$ for $20 \mathrm{~min}$. The extraction with water was repeated twice according to the method of Afify and Ghali (1987).

\section{Extraction of globulin fraction}

The residue from the third water extract was re-extracted with sodium phosphate buffer $(0.2 \mathrm{M}, \mathrm{pH} 7.9)$ containing $0.02 \% \mathrm{NaN}_{3}$ for each peanut and sesame samples according to Chiou and Tasi (1990). While soybean samples was re-extracted with $0.03 \mathrm{M}$ Tris- $\mathrm{HCl}$ buffer $(\mathrm{pH} 8.0)$ buffer in the presence of $10 \mathrm{mM}$ mercapoethanol then the extracts were centrifuged according to Afify and Ghali (1987).

\section{Extraction by SDS, ME 2\% fraction}

The residue from the sodium phosphate buffer extract was re-extracted with sodium phosphate buffer $(0.2$ $\mathrm{M}, \mathrm{pH}$ 7.9) containing $2 \%$ (sodium dodecyl sulfate and 2-mercapto ethanol) for each peanut and sesame samples. While soybean samples was re-extracted with $0.03 \mathrm{M}$ Tris$\mathrm{HCl}$ buffer ( $\mathrm{pH} 8.0$ ) buffer in the presence of $10 \mathrm{mM}$ 2-ME and containing 2\% (sodium dodecyl sulfate and 2-mercapto ethanol) then all samples were centrifuged, according to Afify and Ghali (1987).

\section{Protein determination}

Soluble protein was estimated using the method of Comassie Brilliant Blue G-250 according to Bradford (1976). 
92

\section{Protein solubility}

Protein solubility was expressed as the ratio of soluble protein to total protein according to Estela et al. (1991). Total protein of samples was determined by Kjeldahl method ( $\mathrm{N} \times 6.25)$ according to A.O.A.C. (1990).

\section{Electrophoresis}

Electrophoresis was carried on SDS-PAGE 15\% polyacrylamide in Tris-glycine $\mathrm{pH} 8.3$ with $0.1 \%$ SDS according to the method of Laemmli (1970).

\section{Statistical analysis}

All determinations were done in triplicate. Statistical analysis were done using SPSS (version 10) program. Mean and standard error were descriptive measures of quantitative data using the analysis of variance test (ANOVA) for independent samples. P-values $<0.05$ were considered significant.

\section{Result and discussion}

\section{Soybean protein profiles}

The objective of this investigation was to evaluate the effect of different doses of gamma radiation 0.5, 1.0, 2.0, 3.0, 5.0, and 7.5 KGy on soybean protein patterns. Therefore, different types of protein fractions were extracted from soybean seeds as total soluble protein, albumin, globulin and SDS/ME soluble proteins. The result in Fig. 1 shows that the electrophoretic separation of protein profiles was different according to the extraction methods. The protein profiles of total soluble protein, albumin, globulin and SDS-ME soluble proteins were affected by gamma irradiation depending on the dose of irradiation and protein fractions. Electrophoretic analysis of soybean protein after gamma radiation compared with control sample proved the presence of major protein patterns of $\dot{\alpha}, \alpha$ and $\beta$ with molecular weights 79,70 and $50 \mathrm{~K} \mathrm{Da}$, respectively corresponded to $\beta$-conglycinin.

Two subunits acidic (11S-1) and basic (11S-2) with molecular weights 38 and $26 \mathrm{~K}$ Da which related to glycinin (11S globulin) were identified. On the other hand, the minor protein patterns of agglutinin with molecular weight 34-36 K Da; $\beta$-amylase with molecular weight 55 $\mathrm{K} D \mathrm{a}$ and Kuntiz trypsin inhibitor with molecular weight $21 \mathrm{~K} \mathrm{Da}$ were identified as shown in Fig. 1. Protein globulin fraction of soybean shows an additional protein band with molecular weight $23 \mathrm{~K} \mathrm{Da}$. The intensity of the major subunit bands of 11 S-2 and 11 S-1 with MW of 38 and 26 $\mathrm{K} \mathrm{Da}$, were increased as a results of gamma radiation and reached maximum intensity with 7.5 KGy. On the other hand, most of the remaining protein did not change in its intensity by gamma radiation. It is very important to note that three major protein bands in globulin fraction with MW of 79 ( $\dot{\alpha}$ conglycinin), 38 (acidic 11 S-2) and $34 \mathrm{~K}$ $\mathrm{Da}$ (agglutinin) were increased by increasing gamma irra-

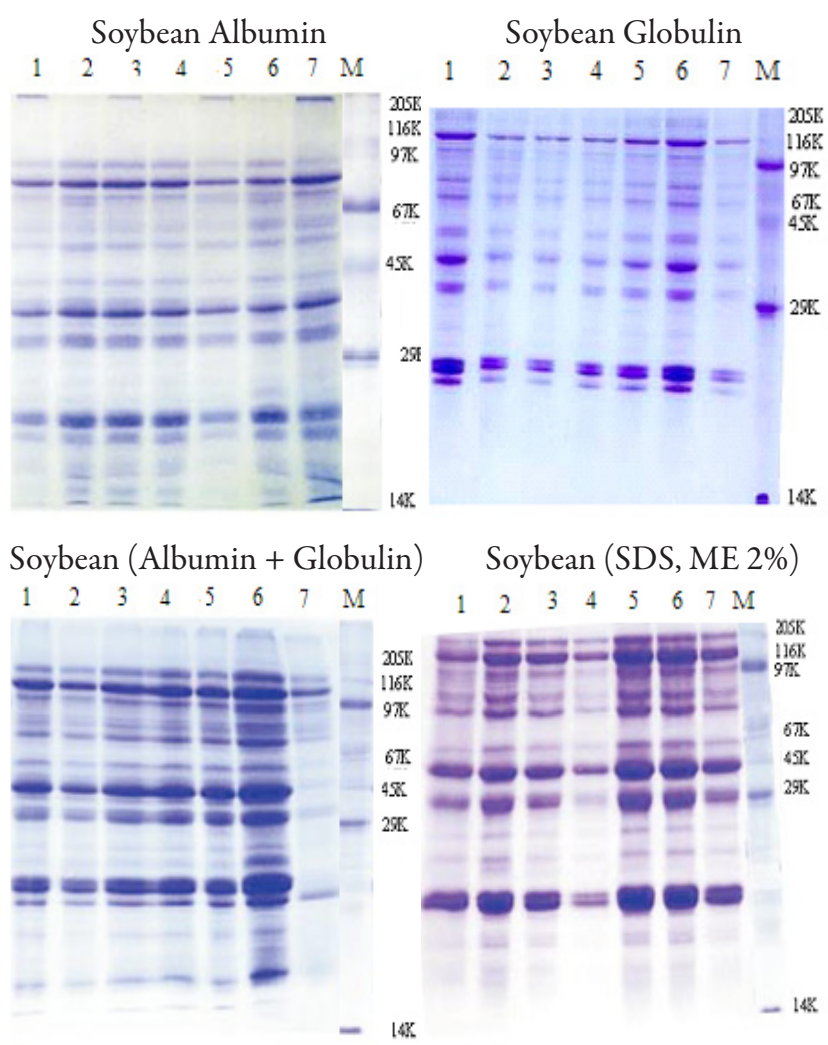

Fig. 1. Electrophoretic separation of protein subunits of soybean in SDS-PAGE 5 and 15\% PAA in Tris-glycine buffer $\mathrm{pH} 8.3$ with $0.1 \%$ SDS. $\gamma$-Radiation treatments; 1 -control, 2-0.5 KGy, 3-1.0 KGy, 4-2.0 KGy, 5-3.0 KGy, 6: 5 KGy, 7-7.5 KGy, M-Molecular weight protein markers

diation and decreased to faint bands with irradiation dose of 7.5 KGy. The results showed that most of the conglycinin and the acidic and basic of glycinin are denatured by gamma radiation rather than destructive because these fractions were solubilized in the SDS-ME soluble fraction of the irradiated samples with different doses.

Since radiation is known to cause disintegration and aggregation of protein molecule this may be occur in the present investigation (Kumta and Tappel, 1961), which will effect on the protein solubility. While it is known that gamma radiation is generally attributed to direct breakdown in protein or enhance the activity of lysozomal (proteolytic) enzyme, which help to aggregate the protein and decrease its solubility (Van Huystee and Verma, 1969). Therefore the irradiation dose used considered very important, since this dose could unfold protein to increase its solubility through the deamination of the protein (Rahma and Mostafa, 1988; Taha and Mohamed, 2004) or aggregate protein during disintegration through the decrease of the sulphahydryl group and increase the disulphide bond (Dogbevi et al., 1999b) and rearrangement of the small molecular weight protein to a high molecular weight and causes decrease in protein solubility (Afify and Shousha, 1988). 
Tab. 1. Protein solubility of different fractions from irradiated Soybean with gamma rays

\begin{tabular}{|c|c|c|c|c|c|c|c|c|c|}
\hline \multirow{3}{*}{$\begin{array}{l}\text { Irradiation } \\
\text { dose (KGy) }\end{array}$} & \multirow{3}{*}{$\begin{array}{c}\text { Total } \\
\text { protein }\end{array}$} & \multicolumn{2}{|c|}{ Total soluble protein } & \multicolumn{2}{|c|}{ Albumin fraction } & \multicolumn{2}{|c|}{ Globulin fraction } & \multicolumn{2}{|c|}{$\begin{array}{c}\text { SDS/MS } \\
\text { soluble protein }\end{array}$} \\
\hline & & $\%$ & $\%$ & $\%$ & $\%$ & $\%$ & $\%$ & $\%$ & $\%$ \\
\hline & & Protein & Solubility & Protein & Solubility & Protein & Solubility & Protein & Solubility \\
\hline $0.0 \mathrm{KGy}$ & $44.6 \pm 0.10$ & $34.0 \pm 0.50^{\mathrm{a}}$ & 76.2 & $19.5 \pm 0.23^{\mathrm{a}}$ & 43.7 & $10 \pm 0.23^{a}$ & 22.4 & $4.5 \pm 0.15^{a}$ & 10.1 \\
\hline $0.5 \mathrm{KGy}$ & $44.3 \pm 0.07$ & $33.5 \pm 0.33^{\mathrm{a}}$ & 75.6 & $18.7 \pm 0.23^{\mathrm{ab}}$ & 42.2 & $9.5 \pm 0.10^{\mathrm{ab}}$ & 21.4 & $4.7 \pm 0.07^{\mathrm{ab}}$ & 10.6 \\
\hline $1.0 \mathrm{KGy}$ & $44.2 \pm 0.07$ & $32.5 \pm 0.29^{\mathrm{ab}}$ & 73.5 & $18.0 \pm 0.30^{\mathrm{bc}}$ & 40.7 & $8.5 \pm 0.44^{\mathrm{bc}}$ & 19.2 & $4.9 \pm 0.08^{b c}$ & 11.1 \\
\hline $2.0 \mathrm{KGy}$ & $44.0 \pm 0.10$ & $32.0 \pm 0.33^{\mathrm{ab}}$ & 72.7 & $17.5 \pm 0.17^{\mathrm{bcd}}$ & 39.7 & $8.3 \pm 0.17^{\mathrm{bcd}}$ & 18.9 & $5.0 \pm 0.15^{\mathrm{cd}}$ & 11.4 \\
\hline $3.0 \mathrm{KGy}$ & $43.7 \pm 0.12$ & $30.0 \pm 0.68^{\mathrm{bc}}$ & 68.7 & $17.0 \pm 0.12^{\mathrm{cd}}$ & 38.9 & $8.0 \pm 0.25^{\mathrm{cd}}$ & 18.3 & $5.7 \pm 0.17^{\mathrm{d}}$ & 13.0 \\
\hline $5.0 \mathrm{KGy}$ & $43.2 \pm 0.09$ & $29.0 \pm 0.58^{c}$ & 67.1 & $16.5 \pm 0.44^{\mathrm{d}}$ & 38.2 & $7.0 \pm 0.32^{d}$ & 16.2 & $6.0 \pm 0.18^{d}$ & 13.9 \\
\hline $7.5 \mathrm{KGy}$ & $42.7 \pm 0.05$ & $28.0 \pm 0.58^{c}$ & 65.6 & $14.5 \pm 0.23^{\mathrm{c}}$ & 34.0 & $6.5 \pm 0.23^{d}$ & 15.2 & $6.5 \pm 0.03^{\mathrm{d}}$ & 15.2 \\
\hline LSD 0.05 & & 2.564 & & 1.341 & & 1.489 & & 0.707 & \\
\hline
\end{tabular}

Data represent the mean \pm S.E. of three experimental replicates. Values with different letters in the same experiment and same column are significantly different $(\mathrm{P} \leq 0.05)$

Protein solubility of soybean seeds

The results in Tab. 1 showed that, the total protein content was not affected by irradiation, while the solubility of total protein fraction was decreased and reached to the maximum decrease using irradiation dose $7.5 \mathrm{KGy}$ (65.6\%) compared to the control (76.2\%). The interesting phenomena are that albumin and globulin fractions decreased in its solubility while SDS-ME fraction increased to reach $15.2 \%$ compared to control $10.1 \%$. Significant differences showed between the total soluble protein and irradiation treatments especially with 3, 5 and 7.5 KGy. The statistical analysis of the albumin, globulin and SDSME soluble protein showed significant changes in protein solubility started from irradiation dose $1 \mathrm{KGy}$. The levels of the significant differences were dependent on the irradiation dose and the methods of protein extraction and have LSD 1.39, 1.48 and 0.707 respectively. These results are in agreement with those found by Diehl et al. (1978) amd Manjaya et al. (2007), cited that irradiation of globular protein causes formation of protein aggregates which effect on its solubility. Byun and Kang (1994) reported that irradiation of soybean proteins caused decrease in the $7 \mathrm{~S}$ and $11 \mathrm{~S}$ fractions and corresponding increase in the 2 $\mathrm{S}$ and $15 \mathrm{~S}$ fractions. Therefore partial degradation of $7 \mathrm{~S}$ globulin into $2 \mathrm{~S}$ protein and aggregation of $11 \mathrm{~S}$ globulin to $15 \mathrm{~S}$ component were proposed as result of ionizing radiation. Disulfide bonds and hydrophobic interactions have been shown to be responsible for decreased protein solubility during extrusion of soy. While significant increasing in protein solubility were noted in SDS-ME soluble fraction after irradiation treatment and reached to its maximum at $7.5 \mathrm{KGy}(15.2 \%)$ compared to control sample $(10.1 \%)$. These phenomena may be due to the direct effect of free radical produced from gamma radiation and affect the protein composition.

Radiation may dissociate these protein fractions to small subunits and rearrangement to form a complex protein even high or small molecular weight compounds (Afify and Shousha, 1988), solubilized only in SDS-ME fraction (Carroll et al., 1952; Néné et al., 1975; Schoweigert, 1959). Gamma irradiation decreased the water soluble fraction and increased the potentially degradable fraction and decreased the degradation rate of the protein. A decrease in protein solubility resulting from irradiation, observed in the present work gives evidence of the occurring cross-linking of chains and proteins aggregation (Delincee and Pushpa, 1981; Nisizawa, 1988; Zabielski et al., 1984). Solubility of proteins relates to surface hydrophobic (protein-protein) and hydrophilic (protein-solvent) interaction (Taha and Mohamed, 2004). Irradiation induces the unfolding of the protein and denaturation, thus exposing non-polar groups that were previously blocked. Thus, gamma-irradiation increased hydrophobicity by exposing non-polar groups. On the other hand, when secondary and tertiary structures of a protein are unfolded, the hydrophobic groups interact and reduce water binding. Moreover, hydrophobic interactions lead to aggregation, followed by coagulation and precipitation (Englard and Seifter, 1990).

\section{Peanut protein profiles}

The results in Fig. 2 showed that, electrophoretic separation of protein profiles were different according to extraction method. The protein profiles of total soluble protein, albumin, globulin and SDS-ME soluble proteins were affected by gamma irradiation depending on the dose of irradiation and protein fractions. Since arachin and conarachin, the two major globulins in peanut comprise more than $85 \%$ of the proteins (Johns and Jones, 1916). The intensity of the five major subunits of the storage protein, arachin with MW 42, 37, 35, 22 and $20 \mathrm{~K} \mathrm{Da}$ (Chiou et al., 1990) were changed in its intensity according to the extraction methods and irradiation dose. Albumin was slightly decreased while most globulin protein fraction bands showed strong intensity especially with 7.5 KGy (Fig. 2). On the other hand the four minor subunits of arachin protein with MW 66, 31, 29 and $25 \mathrm{~K}$ Da did not change in its intensity by gamma radiation. While the intensity of conarachin major subunit with MW $64 \mathrm{~K} \mathrm{Da}$ in the albumin fraction was decreased after different doses of irradiation treatments. The three minor subunits with MW 60, 32 and $21 \mathrm{~K} \mathrm{Da}$ were increased after irradiation 
94

Peanut Albumin Peanut Globulin

$\begin{array}{lllllllllllllllll}1 & 2 & 3 & 4 & 5 & 6 & 7 & \mathrm{M} & 1 & 2 & 3 & 4 & 5 & 6 & 7 & \mathrm{M}\end{array}$

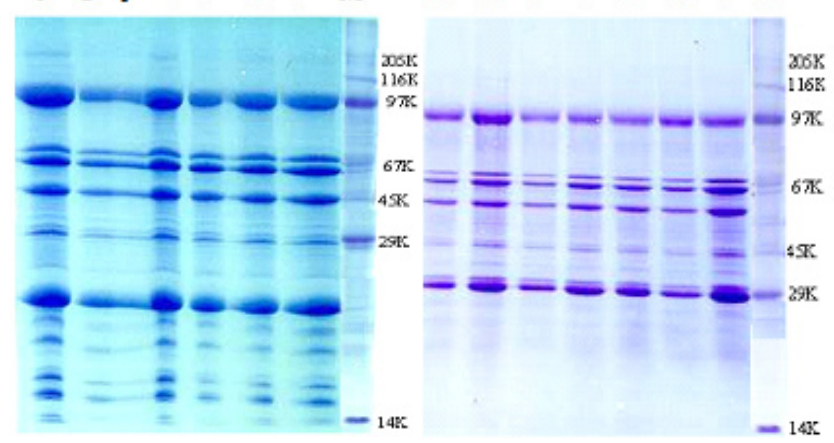

Peanut (Albumin + Globulin) Peanut (SDS, ME 2\%)

$\begin{array}{llllllllllllllll}1 & 2 & 3 & 4 & 5 & 6 & 7 & \mathrm{M} & 1 & 2 & 3 & 4 & 5 & 6 & 7 & \mathrm{M}\end{array}$

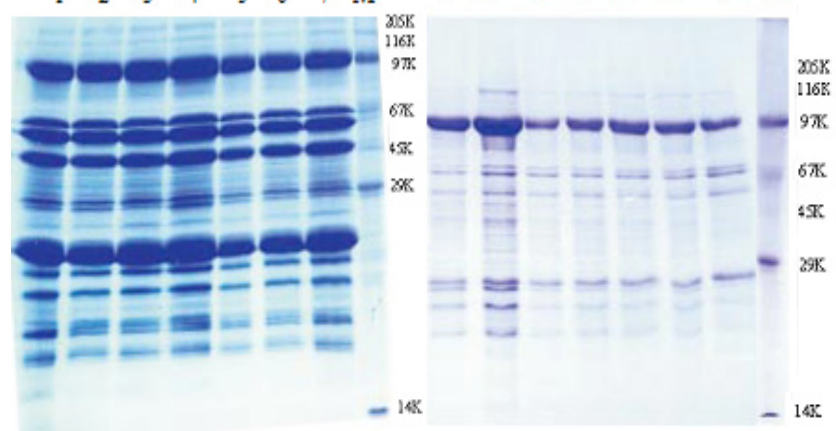

Fig. 2. Electrophoretic separation of protein subunits of peanut in SDS-PAGE 5 and 15\% PAA in Tris-glycine buffer $\mathrm{pH} 8.3$ with $0.1 \%$ SDS. $\gamma$-Radiation treatments; 1-control, 2-0.5 KGy, 3-1.0 KGy, 4-2.0 KGy, 5-3.0 KGy, 6-5 KGy, 7-7.5 KGy, M-Molecular weight protein markers

treatments. Because of irradiation effect there is a minor band with MW $16 \mathrm{~K}$ Da was appeared in irradiated samples in the total soluble protein (albumin + globulin) and its intensities were increased with the increasing in irradiation dose (Fig. 2). The results showed that most of major and minor bands of arachin and conarachin are denatured by gamma radiation rather than destructive because these fractions were re-solubilized in the SDS-ME fraction, es- pecially the conarachin with MW of $64 \mathrm{~K} \mathrm{Da}$ (Fig. 2). The irradiation caused native protein aggregation might simply result from rearrangement of the composed protein subunits (Chiou et al., 1990, 1988; Sonntage, 1987) through a crosslinking of peptides or proteins to form dimers or tetramers by the action of free radicals. (Van Huystee, 1968) the question arose whether this fragmentation was brought about indirectly by enhanced lysozomal (proteolytic) activity, or by a direct effect of radiation such as ionization of the protein chain at the hit sites and perhaps by free radical reactions. Van Huystee (1971), Haskill and Hunt (1967) observed that the results of gel filtration of the irradiated protein arachin with MW $330 \mathrm{~K} \mathrm{Da}$ showed increase in small molecular fragments and causes the formation of disulfide bridges between molecular strands in protein and causes aggregation of the pieces.

\section{Protein solubility of peanut seeds}

The results in Tab. 2 showed that, the total protein content was not affected by irradiation. While the solubility of total protein fraction was decreased and reached to its maximum decrease using irradiation dose $7.5 \mathrm{KGy}$ (60.0\%) compared to control (82.8\%). Results showed significant differences between irradiation treatments and control samples, in the four-protein fractions. The significant differences of the total soluble protein started from dose 2 KGy, while albumin fraction started at 3 KGy. High significant differences could be noted even in globulin or in SDS-ME protein fraction, which started with irradiation dose of $1 \mathrm{KGy}$. The results showed that albumin was decreased in its solubility to $30 \%$ compared to control (43.1\%) while globulin fractions decreased in its solubility from control (31.5\%) compared with $22.1 \%$ in irradiated dose of 7.5 KGy. On the other hand total soluble protein was decreased by $20 \%$ as a result of gamma radiation to 7.5 KGy. These results are in agreement with Diehl (1978), Maity et al. (2009), cited that irradiation of globular protein, caused formation of protein aggregates, and caused decrease in protein solubility.

Tab. 2 Protein solubility of different fractions from irradiated peanut with gamma rays

\begin{tabular}{|c|c|c|c|c|c|c|c|c|c|}
\hline \multirow{3}{*}{$\begin{array}{l}\text { Irradiation } \\
\text { dose (KGy) }\end{array}$} & \multirow{3}{*}{$\begin{array}{c}\text { Total } \\
\text { protein }\end{array}$} & \multicolumn{2}{|c|}{ Total soluble protein } & \multicolumn{2}{|c|}{ Albumin fraction } & \multicolumn{2}{|c|}{ Globulin fraction } & \multicolumn{2}{|c|}{$\begin{array}{c}\text { SDS/MS } \\
\text { soluble protein }\end{array}$} \\
\hline & & $\%$ & $\%$ & $\%$ & $\%$ & $\%$ & $\%$ & $\%$ & $\%$ \\
\hline & & Protein & Solubility & Protein & Solubility & Protein & Solubility & Protein & Solubility \\
\hline $0.0 \mathrm{KGy}$ & $30.2 \pm 0.10$ & $25.0 \pm 0.33^{a}$ & 82.8 & $13.0 \pm 0.54^{\mathrm{a}}$ & 43.1 & $9.5 \pm 0.44^{a}$ & 31.5 & $4.3 \pm 0.60^{a}$ & 14.2 \\
\hline $0.5 \mathrm{KGy}$ & $29.8 \pm 0.13$ & $23.5 \pm 0.17^{\mathrm{ab}}$ & 78.9 & $12.5 \pm 0.33^{\mathrm{a}}$ & 42.0 & $9.0 \pm 0.58^{\mathrm{a}}$ & 30.2 & $4.4 \pm 0.12^{\mathrm{a}}$ & 14.8 \\
\hline $1.0 \mathrm{KGy}$ & $29.6 \pm 0.13$ & $22.5 \pm 0.45^{\mathrm{abc}}$ & 76.0 & $12.3 \pm 0.40^{\mathrm{a}}$ & 41.5 & $7.8 \pm 0.27^{\mathrm{ab}}$ & 26.3 & $4.6 \pm 0.18^{\mathrm{ab}}$ & 15.5 \\
\hline $2.0 \mathrm{KGy}$ & $29.4 \pm 0.03$ & $21.5 \pm 0.45^{b c}$ & 73.1 & $12.0 \pm 0.44^{\mathrm{a}}$ & 40.8 & $7.5 \pm 0.19^{b}$ & 25.5 & $5.5 \pm 0.17^{\mathrm{abc}}$ & 18.7 \\
\hline 3.0 KGy & $29.3 \pm 0.07$ & $20.0 \pm 0.67^{\mathrm{cd}}$ & 68.3 & $11.5 \pm 0.21^{\mathrm{ab}}$ & 39.2 & $7.0 \pm 0.07^{\mathrm{b}}$ & 23.9 & $5.7 \pm 0.32^{\mathrm{bcd}}$ & 19.5 \\
\hline $5.0 \mathrm{KGy}$ & $29.1 \pm 0.12$ & $18.0 \pm 0.58^{\mathrm{d}}$ & 62.0 & $10.0 \pm 0.29^{b c}$ & 34.4 & $7.0 \pm 0.20^{b}$ & 23.4 & $6.0 \pm 0.20^{\mathrm{cd}}$ & 20.6 \\
\hline $7.5 \mathrm{KGy}$ & $29.0 \pm 0.03$ & $17.3 \pm 0.35^{\mathrm{d}}$ & 60.0 & $8.7 \pm 0.15^{c}$ & 30.0 & $6.4 \pm 0.22^{b}$ & 22.1 & $6.1 \pm 0.19^{d}$ & 21.0 \\
\hline LSD 0.05 & & 3.163 & & 1.889 & & 1.702 & & 0.404 & \\
\hline
\end{tabular}

Data represent the mean \pm S.E. of three experimental replicates. Values with different letters in the same experiment and same column are significantly different $(\mathrm{P} \leq 0.05)$ 
Tab. 3. Protein solubility of different fractions from irradiated Sesame with gamma rays

\begin{tabular}{|c|c|c|c|c|c|c|c|c|c|}
\hline \multirow{3}{*}{$\begin{array}{l}\text { Irradiation } \\
\text { dose (KGy) }\end{array}$} & \multirow{3}{*}{$\begin{array}{c}\text { Total } \\
\text { protein }\end{array}$} & \multicolumn{2}{|c|}{ Total soluble protein } & \multicolumn{2}{|c|}{ Albumin fraction } & \multicolumn{2}{|c|}{ Globulin fraction } & \multicolumn{2}{|c|}{$\begin{array}{c}\text { SDS/MS } \\
\text { soluble protein }\end{array}$} \\
\hline & & $\%$ & $\%$ & $\%$ & $\%$ & $\%$ & $\%$ & $\%$ & $\%$ \\
\hline & & Protein & Solubility & Protein & Solubility & Protein & Solubility & Protein & Solubility \\
\hline $0.0 \mathrm{KGy}$ & $28.6 \pm 0.07$ & $24.0 \pm 0.33^{a}$ & 83.9 & $9.0 \pm 0.22^{\mathrm{a}}$ & 31.5 & $13.0 \pm 0.17^{\mathrm{a}}$ & 45.5 & $2.3 \pm 0.10^{a}$ & 8.0 \\
\hline $0.5 \mathrm{KGy}$ & $27.8 \pm 0.03$ & $22.0 \pm 0.38^{\mathrm{ab}}$ & 79.1 & $8.4 \pm 0.12^{\mathrm{ab}}$ & 30.2 & $12.5 \pm 0.12^{\mathrm{a}}$ & 45.0 & $3.2 \pm 0.20^{\mathrm{a}}$ & 11.5 \\
\hline $1.0 \mathrm{KGy}$ & $27.5 \pm 0.13$ & $21.0 \pm 0.5^{\mathrm{ab}}$ & 76.7 & $8.2 \pm 0.15^{\mathrm{ab}}$ & 29.8 & $12.3 \pm 0.38^{\mathrm{ab}}$ & 44.7 & $3.5 \pm 0.12^{\mathrm{a}}$ & 12.7 \\
\hline $2.0 \mathrm{KGy}$ & $27.3 \pm 0.07$ & $19.6 \pm 0.62^{\mathrm{bc}}$ & 71.8 & $6.7 \pm 0.24^{c}$ & 24.5 & $11.7 \pm 0.52^{b}$ & 42.9 & $5.5 \pm 0.03^{b}$ & 20.0 \\
\hline $3.0 \mathrm{KGy}$ & $27.1 \pm 0.10$ & $18.0 \pm 0.29^{\mathrm{bc}}$ & 66.4 & $6.5 \pm 0.21^{\mathrm{c}}$ & 24.0 & $11.5 \pm 0.17^{b}$ & 42.4 & $6.5 \pm 0.12^{c}$ & 24.0 \\
\hline $5.0 \mathrm{KGy}$ & $27.0 \pm 0.07$ & $17.7 \pm 0.35^{\mathrm{bc}}$ & 65.6 & $6.4 \pm 0.19^{c}$ & 23.7 & $11.0 \pm 0.32^{\mathrm{b}}$ & 40.7 & $6.7 \pm 0.06^{\mathrm{d}}$ & 24.8 \\
\hline $7.5 \mathrm{KGy}$ & $26.5 \pm 0.10$ & $17.0 \pm 0.33^{c}$ & 64.2 & $6.0 \pm 0.33^{c}$ & 22.6 & $10.7 \pm 0.21^{b}$ & 40.4 & $6.9 \pm 0.19^{d}$ & 26.0 \\
\hline LSD 0.05 & & 3.808 & & 0.708 & & 1.474 & & 0.692 & \\
\hline
\end{tabular}

Data represent the mean \pm S.E. of three experimental replicates. Values with different letters in the same experiment and same column are significantly different $(\mathrm{P} \leq 0.05)$

\section{Sesame protein profiles}

The results in Fig. 3 showed that, some changes were detected after the gamma irradiation treatment in the protein profiles of albumin, globulin and SDS-ME soluble protein fractions. On the other hand, no changes were noted in total soluble protein fraction. In albumin fraction, two bands with high molecular weight $118,76 \mathrm{~K} \mathrm{Da}$ have been detected in seeds irradiated with the high doses of gamma irradiation $(3,5,7.5 \mathrm{KGy})$ while one minor protein band with molecular weight $18 \mathrm{~K} \mathrm{Da}$ was detected at the same doses. These three bands could not be detected ether in control or in seeds irradiated with low doses of gamma irradiation $(0.5,1$ and $2 \mathrm{KGy})$. The appearance of high molecular weight protein was in agreement with the results of aggregation of a special protein to produce high molecular weight proteins as a result of $\gamma$-irradiation (Diehl et al., 1978). On the other hand, the intensities of two minor bands with molecular weight $16,20 \mathrm{~K} \mathrm{Da}$ were decreased at gamma irradiation dose 2, 3 and 5 KGy. A new protein band with MW of $40 \mathrm{~K} \mathrm{Da}$ could be detected in sesame irradiated with $3 \mathrm{KGy}$. The results are in agreement with the finding of Afify et al. (1992a), Gralik and Warchalewski (2006) who showed that, irradiation of an aqueous solution of serum albumin or wheat albumin produced destruction in its amino acid content. The present results were in agreement with (Afify and Shousha, 1988) who reported that irradiation caused slight differences in albumin protein band intensities and inactivation of enzyme and polymerization and aggregation of simple protein. In globulin fraction, the intensities of the three major subunits with molecular weight 35,30 and $20 \mathrm{~K} \mathrm{Da}$ was increased as a result of gamma radiation doses and reached to maximum intensity with $7.5 \mathrm{KGy}$.

On the other hand the intensities of the four minor bands with molecular weight $33,16,15$ and $14 \mathrm{~K} \mathrm{Da}$ was increased also as a result of gamma irradiation and reached to its maximum with $7.5 \mathrm{KGy}$. The low molecular weight proteins of 17,18 and $19 \mathrm{~K} \mathrm{Da}$ were increased in their intensity especially after $0.5 \mathrm{KGy}$ and the intensities of the bands were decreased by increasing the irradiation dose.
The changes in globulin fraction were probably due to radiation induced protein denaturation and degradation of the insoluble protein fraction as stated by Chow and Subha (1985), Afify and Shousha (1988), Afify et al. (1992b). The slight changes in protein patterns after SDS-PAGE separation in sesame seeds after irradiation may be due to slight changes in bonds stabilized protein conformation or due to slight destructive in some aromatic and heterocyclic amino acid residues (Taub et al., 1976), and the possibility of rearrangement (Sonntage, 1987).

$$
\text { Sesame Albumin Sesame Globulin }
$$

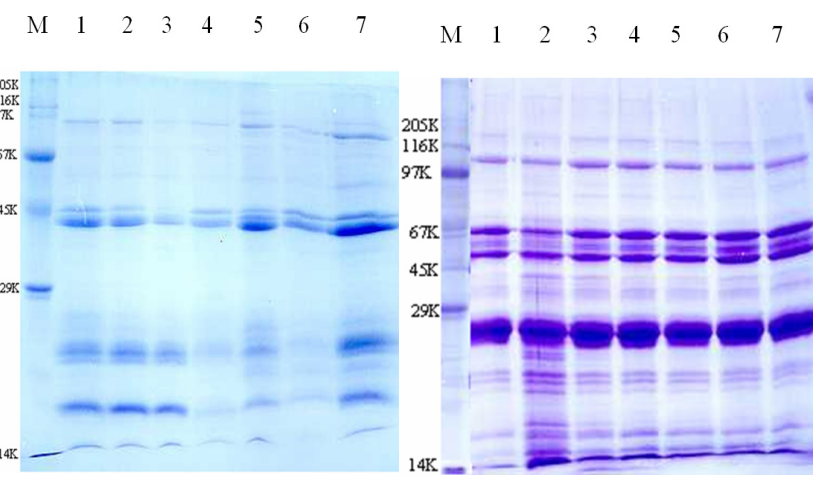

Sesame (Albumin + Globulin)

Sesame (SDS, ME 2\%)

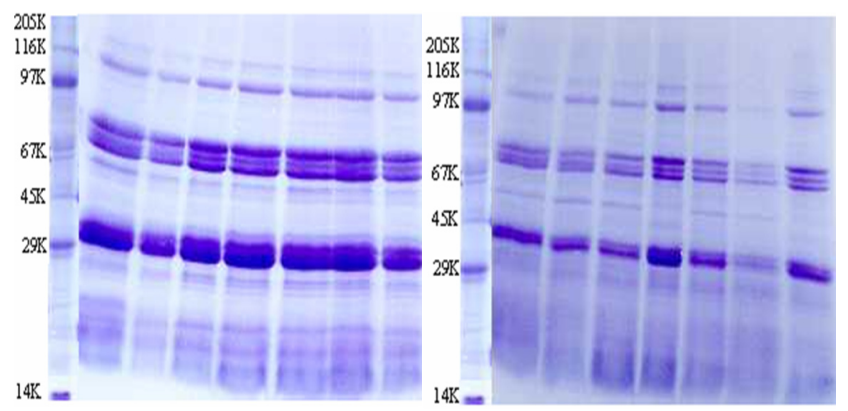

Fig. 3. Electrophoretic separation of protein subunits of sSesame in SDS-PAGE 5 and 15\% PAA in Tris-glycine buffer $\mathrm{pH} 8.3$ with $0.1 \%$ SDS. $\gamma$-Radiation treatments; 1-control, 2-0.5 KGy, 3-1.0 KGy, 4-2.0 KGy, 5-3.0 KGy, 6-5 KGy, 7-7.5 KGy, M-Molecular weight protein markers 
96

Protein solubility of sesame seeds

The results in Tab. 3 showed that, the total protein content was not affected by irradiation, while the solubility of total protein fraction were decreased and reached to the maximum decrease using irradiation dose $7.5 \mathrm{KGy}$ (64.2\%) compared to the control (83.9\%). Significant differences could be noted by comparing statistical analysis especially LSD and coefficient of variation of irradiated seeds for the three protein fractions; total soluble protein, albumin and SDS-ME soluble protein. On the other hand globulin fraction showed no significant differences. The significant differences in three protein fractions started at the same level of irradiation dose of 2 KGy. Therefore this dose considered the very important one and taken in the consideration during the irradiation of sesame to keep the protein quality and quantity of the irradiated seeds for commercial use. These results are in agreement with those found by Afify et al. (1992a). Such protein solubility reduction was probably due to radiation induced protein denaturation of sesame (Chow and Subha, 1986) and aggregations of protein (Sonntage, 1987).

\section{Conclusions}

One of the interests in this investigation was to determine the mechanisms might be causes fragmentation of protein during radiation exposure of oil seeds peanut, soybean and sesame seeds. The direct breakdown of the molecule by ionization capacity of the passing photon may be one possibility. In addition, radiation normally cause the formation of disulphide bridge between polypeptide chain which may be effect on the aggregation of the low molecular weight protein and effect on its conformation and solubility. While the other the enzymatic breakdown of the protein and enzyme molecule due to the stimulation of hydrolytic activity by radiation. It is concluded that implementing gamma radiation up to $7.5 \mathrm{kGy}$ on the three oil seeds, will affect total soluble protein, albumin and globulin fractions as well as SDS/ME fraction. As a general trend intensity of bands was decreased with the increased gamma dose.

\section{Acknowledgments}

Authors would like to thank the management of the Faculty of Agriculture and, Cairo University for ongoing cooperation to support research and that provided funds and facilities necessary to achieve the desired goals of research.

\section{References}

Afify AMR, Ghali Y (1987). Effect of different method of extraction on the protein patterns of stored and fresh onion seeds evaluated by polyacrylamide gel electrophoresis. Annal Agric Moshtohor 25(1):265-275.

Afify AMR, Hammam MA, Ragab AR, Rashed MA (1992a).
Effect of low doses gamma radiation on Globulin, RNA and Protein Bands of lentil seeds (Lens cultinaris) during germination. Minufiya J Agric Res 17(2):345-363.

Afify AMR, Saker AA, Afify AS, Abo El-Seoud MA (1992b). Biochemical changes in albumin, nucleic acids and protein of irradiated lentil seeds (Lens cultinaris) during germination. Minufiya J Agric Res 17(2):321-343.

Afify AMR, Shousha MA (1988). Effect of low-dose irradiation on soybean protein solubility, trypsin inhibitor activity and protein patterns separated by polyacrylamide gel electrophoresis. J Agric Food Chem 36(4):810-813.

Afify AMR, El-Beltagi HS (2011). Effect of the insecticide cyanophos on liver function in adult male rats. Fresen Environ Bull 20(4):1084-1088.

Afify AMR, El-Beltagi HS, Fayed SA, Shalaby EA (2011). Acaricidal activity of successive extracts from Syzygium cumini L. Skeels (Pomposia) against Tetranychus urticae Koch. Asian Pac J Trop Biomed 1(5):359-364.

Aly AA, El-Beltagi HES (2010). Influence of ionizing irradiation on the antioxidant enzymes of Vicia faba L. Grasas Y Aceites 61(3):82-94.

Ali SM, Olivo M (2002). Bio-distribution and subcellular localization of Hypericin and its role in PDT induced apoptosis in cancer cells. Int J Oncol 21:531-540.

AOAC (1990). Official methods of analysis of official analytical chemists. Pub. by the Association of Analytical Chemists, Inc., Arlington, West Virginia, USA.

Ashri A (2007). Sesame (Sesamum indicum L.), 231-289 p. In: Singh RJ (Ed.). Genetics Resources, Chromosome Engineering, and Crop Improvement, Vol. 4, Oilseed Crops, CRC Press, Boca Raton, FL.

Basha SMM, Cherry JP, Young CT (1976). Changes in free amino acids, carbohydrates and proteins of maturating seeds from various peanut (Arachis hypogaea L.) cultivars. Cereal Chem 53(4):586-597.

Bradford MM (1976). A Rapid and sensitive method for the quantitation of microgram quantities of protein utilizing the principle of protein-dye binding. Anal Biochem 72:248254.

Byun MW, Kang IJ (1994). Effect of $\gamma$-Irradiation on Soya Bean proteins. J Sci Food Agric 66:55-60.

Carroll WR, Mitchell ER, Callahan MJ (1952). Polymerization of serum albumin by $\mathrm{x}$-rays. Arch Biochem Biophys 39(1)232:233.

Casarett AP (1968). Radiation chemistry. American Institute of Biological Sciences, Prentice Hall, NJ.

Chiou RYY, Hus CS, Tyan FZ, Tasi CL (1988). Physiochemical study of peanut proteins with various cultivars grown on Taiwan. J Chin Agric Chem Soc 26:188-189.

Chiou RYY, Tasi CL (1989). Characterization of peanut during roasting as affected by initial moisture content. J Agric Food Chem 37:1377-1381.

Chiou RYY, Shyu SL, Tasi CL (1990). Characterization of 
gamma irradiated peanut kernels stored one year under ambient and frozen conditions. J Food Sci 56(5):1375-1377.

Chow KH, Subha N (1985). Effect of gamma rays on winged bean tissues culture in vitro. IAEA-SM 282(10):175-179.

Delincee H, Pushpa P (1981). Protein aggregation in foods models: effect of g-irradiation and lipid oxidation. J Food Process Preserv 5:145-159.

Diehl JF (1978). Safety of irradiated foods. Markel Dekker, INC. NY, 43-44 p.

Dogbevi MK, Vachon C, Lacroix M (1999a). Physiochemical properties of dry red kidney Bean proteins and natural microflora as affected by gamma irradiation. J Food Sci 4(3):40-42.

Dogbevi MK, Vachon C, Lacroix M (1999b). Physiochemical and microbial changes in irradiated fresh pork loins. Meat Sic 51:349-354.

Doguchi M (1969). Effects of gamma irradiation on wheat gluten. Agr Bio Che 33:1769-1774.

El-Beltagi HES, Salama ZA, DM El-Hariri (2008). Some Biochemical Markers for Evaluation of Flax Cultivars under Salt Stress conditions. J Nat Fibers 5(4):316-330.

El-Beltagi HS, Mohamed AA, Rashed MM (2010). Response of antioxidative enzymes to cadmium stress in leaves and roots of Radish. Not Sci Biol 2(4):76-82.

El-Beltagi HS, Mohamed AA (2010). Changes in non protein thiols, some antioxidant enzymes activities and ultrastructural alterations in Radish plants (Raphanus sativus L.) grown under lead toxicity. Not Bot Horti Agrobo 38(3):76-85.

El-Beltagi HES (2011). Effect of roasting treatments on protein fraction profiles, some enzyme activities of Egyptian peanuts. Int J Food Sci Nutr 62(5):453-456.

El-Beltagi HS, Ahmed OK, El-Desouky W (2011). Effect of low doses $\gamma$-irradiation on oxidative stress and secondary metabolites production of Rosemary (Rosmarinus officinalis L.) callus culture. Radiat Phys Chem 80(9):968-976.

Englard S, Seifter S (1990). Precipitation techniques. Methods Enzymol 182:285-300.

EstelaLA,DeliaAS,JorgeRW,MariaCA(1991).Electrophoretic, solubility, and functional properties of commercial soy protein isolates. J Agric Food Chem 39:1029-1032.

Gralik J, Warchalewski J (2006). The influence of g-irradiation on some biological activities and electrophoresis patterns of wheat grains albumin fraction. Food Chem 99:289-298.

Hafez YS, Mohamed AI, Singh G, Hewedy FM (1985). Effect of gamma irradiation on protein and fatty acids of soybean. J Food Sci 50(2):1271-1276.

Haskill JS, Hunt JW (1967). Radiation damage to crystalline RNA-ase identification of polypeptide chain breakage in the denatured and aggregated products. Radiat Res 32:827848.

Hirano H, Kagawa H, Kamata Y, Yamauchi F (1987). Structural homology among the major $7 \mathrm{~S}$-globulin subunits of soybean seed storage proteins. Phytochem 26:41-45.

IAEA (1977). Manual on mutation breeding. $2^{\text {nd }}$ Ed., Technical Reports Series No. 119. IAEA, Vienna, 288 p.

Ibrahim NM, Eweis EA, El-Beltagi HS, Abdel-Mobdy YE (2011). The effect of lead acetate toxicity on experimental male albino rat. Biol Trace Elem Res (in Press)

Iwabuchi S, Yamauchi F (1987a). Determination of glycinin and $\beta$-conglycinin in soybean proteins by immunological methods. J Agric Food Chem 35:200-205.

Iwabuchi S, Yamauchi F (1987b). Electrophoretic analysis of whey proteins presents in soybean globulin fractions. J Agric Food Chem 35:205-209.

Johns CO, Jones DB (1916). The proteins of the peanut, Arachis bypogaea L. The globulins arachin and conarachin. J Biol Chem 28:77-87.

Kobeasy MI, El-Beltagi HS, El-Shazly MA, Khattab EAH (2011). Induction of resistance in Arachis hypogaea L. against Peanut Mottle Virus by nitric oxide and salicylic acid. Physiol Mol Plant Pathol (in Press).

Kumta US, Tappel AL (1961). Radiation damage to proteins. Nature 191:1304-1305.

Laemmli UK (1970). Cleavage of structural proteins during the assembly of head of bacteriophage T4. Nature 227:680685.

Lee CC (1962). Electron para magnetic resonance (EPR) and baking studies on gamma irradiated flour. Cereal Chem 39:147-150.

Lee S, Lee M, Song K (2005). Effect of gamma-irradiation on the physicochemical properties of gluten films. Food Chem 92:621-925.

O’Kane DV, Gill PB, Burdon R (1996). Chilling, oxidative stress and antioxidant response in Arabidopsis thaliana callus. Planta 198:371-377.

Maity JP, Chakraborty S, Kar S, Panja S, Jean J, Samal AC, Chakraborty A, Santra SC (2009). Effects of gamma irradiation on edible seed protein, amino acids and genomic DNA during sterilization. Food Chem 114:1237-1244.

Manjaya JG, Suseelan KN, Gopalakrishna T, Pawar SE, Bapat VA (2007). Radiation induced variability of seed storage proteins in soybean [Glycine max (L.) Merrill]. Food Chem 100:1324-1327.

Mohamed AA, El-Beltagi HS, Rashed MM (2009). Cadmium stress induced change in some hydrolytic enzymes, free radical formation and ultrastructural disorders in Radish plant. EJEAF Chem 8(10):969-983.

Néné SP, Valul UK, Sreenivasan A (1975). Effect of gamma irradiation on red grain (Cajanus cajun) protein. J Food Sci 48:1791-1795.

Nisizawa M (1988). Radiation induced sol-gel transition of protein: effect of radiation on amino-acid composition and viscosity. J Appl Polym Sci 36:979-981.

Rahma EH, Mostafa MM (1988). Functional properties of peanut flour as affected by different heat treatments. J Food 
98

\section{Sci Technol 25:11-15.}

Sadeghi AA, Shawrang P (2006). Effects of microwave irradiation on ruminal degradability and in vitro digestibility of canola meal. Anim. Feed Sci Technol 127:45-54.

Salama ZA, El-Beltagi HS, El-Hariri DM (2009). Effect of Fe deficiency on antioxidant system in leaves of three flax cultivars. Not Bot Horti Agrobo 37(1):122-128.

Schweigert BS (1959). The effect of radiation on proteins. Int J App Rad Isotopes 6:75-76.

Shehab GMG, Ahmed OK, El-Beltagi HS (2010). Nitric oxide treatment alleviates drought stress in rice plants (Oryza sativa). Not Bot Horti Agrobo 38(1):139-148.

Taha FS, Mohamed SS (2004). Effect of different denaturating methods on lipid-protein complex formation. LebensmittelWissenschaft und-Technologie 37:99-104.

Siddiqui BA, Khan S (1999). Breeding in Crop Plants: Mutations and in Vitro Mutation Breeding. 1st ed. Kalyani Publishers, Ludhiana.

Taub IA, Angilini P, Merritt C (1976). Irradiation food: validity of extrapolating wholesomeness data. J Food Sci 41:942944.
Van Huystee RB (1968). Effect of massive X-irradiation on proteins and protein synthesis in peanut cotyledons. Can J Biochem 46:685-689.

Van Huystee RB, Verma DPS (1969). The incorporation of leucine in cotyledons of control and irradiated peanut seeds Arachis hypogaea L.). Radiat Bot 9:323-332.

Van Huystee RB (1971). Fragmentation of a storage protein, arachin, by gamma radiation. Radiat Bot 11:287-292.

Von Sonntage C (1987). The chemical basis of radiation biology. Taylor and Francis Ltd, London, England.

WHO (1999). High-dose Irradiation: Wholesomeness of Food Irradiated with Doses above 10 kGy. WHO, Geneva.

Zabielski J, Kijowski J, Fiser W, Niewiarowicz A (1984). The effect of irradiation on technological properties and protein solubility of broiler chicken meat. J Sci Food Agric 35: $662-$ 670. 